\title{
Rzecz prywatna, rzecz sekretna. O granicach intymności w korespondencji Marii Dąbrowskiej i Anny Kowalskiej z lat 1946-1948
}

\author{
Ewa GŁęBicka \\ (Instytut Badań Literackich PAN, Warszawa)
}

Długoletnia korespondencja Marii Dąbrowskiej z Anną Kowalską z lat I940-I964 jest najobszerniejszym z ich zbiorów epistolarnych; liczy 2343 listy, najczęściej kilkustronicowe, złożone przez spadkobierców w Muzeum Literatury w Warszawie ${ }^{\mathrm{I}}$. Ze względu na jego rozmiary i dynamikę, w prezentowanym omówieniu zamierzam skupić się na najbardziej dramatycznym czasie w relacjach i w korespondencji pisarek, tj. na okresie od początku roku 1946, kiedy Dąbrowska dowiedziała się o ciąży przyjaciółki, do końca 1948 roku.

Kobiety spotkały się po raz pierwszy w domu Izydora i Stanisławy Blumenfeldów² we Lwowie, dokąd Dąbrowska i Stanisław Stempowski ${ }^{3}$ przedostali się

1 W Katalogu rękopisów Muzeum Literatury, t. 5 (Warszawa 2017) zapisane zostały jako: Listy Anny Kowalskiej do Marii Dąbrowskiej (990 listów w t. I-XV, sygn. 2063, 1816 kart); Listy Marii Dąbrowskiej do Anny Kowalskiej (1346 listów w t. I-XXI, sygn. 2153,2471 kart).Jedynie siedem pojedynczych listów Kowalskiej do Dąbrowskiej z lat 1942-1954 znajduje się w Gabinecie Rękopisów Biblioteki Uniwersytetu Warszawskiego (Korespondencja prywatna Marii Dąbrowskiej, sygn. 1385; karty 185-195). Niemal wszystkie wyróżnienia w cytatach pochodzą od autorek (o nadawcy informują inicjały, umieszczone na końcu przytoczonego fragmentu w nawiasie zwykłym, przed datą listu). Ingerencja edytorska została zaznaczona w nawiasie kwadratowym.

2 Izydor Blumenfeld (zm. 1944), przemysłowiec, właściciel fabryki farmaceutycznej Laokoon we Lwowie. $Z$ wykształcenia matematyk, był biografem Izaaka Newtona. Wraz ze Stanisławem Vincenzem przełożył Wszechideat Rudolfa Marii Holzapfla (Warszawa 1935). Po wkroczeniu do Lwowa armii niemieckiej Blumenfeldowie włączyli się w działania konspiracyjne.

Stanisława Blumenfeldowa z d. Adolfówna (primo voto Bałabanowa) (ok. 1900-1942), żona Izydora, siostrzenica Ostapa Ortwina. W latach 1931-1935 uczestniczyła w akcji pomocowej najuboższym, zwanej Akcją Błękitnych. Należała do współzałożycieli „Sygnałów”; w 1936 r. odeszła z redakcji, po czym współpracowała z miesięcznikiem „Lwów Literacki”, około 1938 założyła we Lwowie Towarzystwo Miłośników Muzyki. Okoliczności jej śmierci nie są znane; zginęła pod koniec grudnia 1942 r. w więzieniu przy ulicy Łąckiego lub na Górze Piaskowej we Lwowie.

3 Stanisław Stempowski (1870-1952), ojciec Jerzego, działacz społeczny, pisarz, tłumacz z literatury rosyjskiej, bibliotekarz, członek redakcji pism „Prawda” (do 1900) i „Ogniwo”(1902-1905), sympatyk socjalizmu, czynny działacz Warszawskiego Koła Oświaty Rolniczej, wolnomularz. W latach 1924-1939 pracował jako bibliotekarz w Ministerstwie Rolnictwa i Reform Rolnych, gdzie poznała go Dąbrowska. Po śmierci Mariana Dąbrowskiego w 1925 r. zaprzyjaźnili się, od 1926 r. pozostawali w stałym związku. Należał do głupy/działączy yłdajacej pamiętniki chłopów i bezrobotnych w In- 
po wybuchu drugiej wojny światowej. Autorka Nocy $i$ dni znała Blumenfeldową od I938 roku, gdy ta $\mathrm{z}$ ramienia lwowskiego oddziału Towarzystwa Uniwersytetu Robotniczego zaprosiła ją z odczytem do Lwowa. Przez mieszkanie Blumenfeldów przewinęły się po wrześniu 1939 roku rzesze uciekinierów, stale bywali w nim zaprzyjaźnieni z rodziną m.in. Jan Kott ${ }^{4}$ ze świeżo poślubioną żoną Lidią ze Steinhausów, jej ojciec Hugo Steinhaus ${ }^{5}$ oraz Jerzy i Anna Kowalscy ${ }^{6}$. To wtedy Dąbrowska przeszła inicjację homoerotyczną, wchodząc we wprawdzie krótkotrwałą, ale być może ważącą na dalszych jej wyborach intymną relację z Blumenfeldową. Dwie kolejne próby powrotu Dąbrowskiej i Stempowskiego do domu nie powiodły się i musieli cofnąć się do Lwowa, gdzie tym razem zatrzymali się m.in. w domu Kowalskich; do Warszawy udało im się wyjechać dopiero w połowie czerwca 1940 roku. W sierpniu i94I roku Dąbrowska otrzymała pierwsze po wybuchu wojny niemiecko-sowieckiej listy ze Lwowa: od Kowalskiej i Blumenfeldowej. W listopadzie 194I roku wyjechała do Lwowa, by spotkać się z Blumenfeldową; udało się jej powrócić po trzech tygodniach; w Dziennikach notowała: „Mieszkałam u Anny. Rozluźnienie przyjaźni ze Stasią, zacieśnienie przyjaźni z Anną” (Dz., I XII 1942)7. Gdy pod koniec grudnia otrzymała wiadomość o śmierci przyjaciółki, pisała: „zamordowana przez Niemców. Jestem zupełnie zdruzgotana i ani na chwilę z myśli i z oczu mi nie schodzi jej wdzięczna postać. Tak skończyła się ostatnia miłość mojego życia” (Dz., 22 XII 1942). W połowie marca 1943 roku do Warszawy przy-

stytucie Gospodarstwa Społecznego. Pośmiertnie ukazały się jego Pamiętniki 1870-1914 z przedmową Marii Dąbrowskiej (1953).

4 Jan Kott (1914-2001), krytyk i historyk literatury i teatru, tłumacz.W 1939 r. poślubił Lidię z d. Steinhaus. We Lwowie przebywał do 1941 r., pracując m.in. w Zakładzie Narodowym im. Ossolińskich. Przystąpił do Związku Pisarzy Radzieckich Ukrainy. Następnie wyjechał do Warszawy, gdzie działał w konspiracji. Po wojnie zamieszkał w Łodzi. Był współredaktorem i współtwórcą programu literackiego „Kuźnicy” $i$ jednym $z$ animatorów marksizmu w powojennym literaturoznawstwie, później rzecznik tendencji awangardowych w teatrze. W latach 1949-1952 był profesorem Uniwersytetu Wrocławskiego, następnie Uniwersytetu Warszawskiego. Od 1966 r. przebywał w USA, gdzie od 1968 r. wykładał na uniwersytecie w Stony Brook. Był autorem odkrywczych interpretacji dramatów Williama Szekspira.

5 Hugo Steinhaus (1887-1972), polski matematyk należący do tak zwanej lwowskiej szkoły matematycznej, założyciel (wspólnie ze Stefanem Banachem) pisma „Studia Mathematica”. W 1939 r. po zajęciu Lwowa przez ZSRR otrzymał nominację na profesora Katedry Analizy Wyższej w Państwowym Uniwersytecie Ukraińskim im. Iwana Franki oraz pracownika naukowego Akademii Nauk w Kijowie. Po wkroczeniu wojsk niemieckich do Lwowa w czerwcu 1941 r., wraz z rodziną kilka miesięcy ukrywał się u tamtejszych znajomych, po czym w lipcu 1942 r. przedostał się do Berdechowa koło Gorlic.

6 Jerzy Kowalski (1893-1948), filolog klasyczny, pisarz, od 1920 r. profesor Uniwersytetu Jana Kazimierza we Lwowie, a następnie od 1945 Uniwersytetu Wrocławskiego, autor prac m.in. z zakresu retoryki, historii, geografii i etnografii; tłumacz kilku mów Demostenesa, komentator wykładów lozańskich Adama Mickiewicza (w 7 tomie wydania sejmowego, 1936), autor (wspólnie z żoną) kilku powieści i opowiadań.

7 Nieliczne cytaty z Dzienników Marii Dąbrowskiej (t. 1-13, Warszawa 2009) w tym tekście oznaczono skrótem „Dz.” oraz datą dzienną zapisu. 
jechała Kowalska, która zameldowała się w mieszkaniu Dąbrowskiej, a wkrótce wynajęła wraz z mężem mieszkanie sąsiadujących z Dąbrowską Pauliny i Zygmunta Kmitów ${ }^{8}$. Rok 1943 to początek nowego związku, który stanie się cezurą w życiu Dąbrowskiej i spowoduje, że na długi czas pisarka straci siły twórcze, będąc zdolna niemal wyłącznie do pisania listów do Anny. „Szaleństwo Anny, na które nie potrafię poradzić, któremu ulegam, i z którym nie wiem, co robić. Ogarnia mnie przerażenie” (Dz., 26 III I943). „Aby ci przynieść szklankę wody, chętnie obiegłabym kulę ziemską po równoleżniku" (A. K., I4-I5 IX I943) ${ }^{9}$ - to słowa z listu Kowalskiej, które stanowiły dla Dąbrowskiej klucz do planowania ich wspólnej przyszłości i do których potem wracała w swojej korespondencji. Pozostały w tym trudnym związku, naznaczonym pewnością prawa do miłości, głęboką przyjaźnią, przywiązaniem, ale też wątpliwościami i pretensjami do końca życia Dąbrowskiej w maju 1965 roku. Życiowe etapy tego związku wyznaczyły narodziny córeczki Kowalskich w maju 1946 roku, choroba i śmierć Jerzego Kowalskiego w styczniu 1948 roku i śmierć Stanisława Stempowskiego w styczniu I952 roku, a następnie przeprowadzka Kowalskiej do Warszawy w 1954 roku.

Swoje powojenne życie pisarki porządkowały i układały w zgoła odmiennych warunkach. Dąbrowska wraz ze Stempowskim wróciła do swojego przedwojennego mieszkania przy ul. Polnej, Kowalscy - utraciwszy swoje lwowskie życie, szukali dla siebie nowego miejsca. Ostatecznie w październiku 1945 roku osiedli we Wrocławiu, gdzie Jerzemu Kowalskiemu powierzono współtworzenie Wydziału Humanistycznego Uniwersytetu Wrocławskiego, Kowalska podjęła zaś działalność literacką i kulturalną jako założycielka i przewodnicząca Koła Miłośników Literatury i Języka Polskiego, organizatorka czwartków literackich oraz wspólnie z Tadeuszem Mikulskim redaktorka „Zeszytów Wrocławskich”. Lata pobytu Anny we Wrocławiu to czas najintensywniejszej korespondencji pisarek: blisko 2000 listów, z których przedmiotem obecnych rozważań będzie ponad 600 z lat 1946-1948.

Opisywane przez Kowalską obrazy opuszczonego wprawdzie przez armię niemiecką, ale zajętego przez Rosjan i nielicznych jeszcze Polaków Wrocławia poruszają wyrazistością i dramatyzmem.

\Drogą nad Odrą ciągną wozy sow[ieckie] z łupem. Bez końca: opony, tysiącami konie, wozy z mąką, fotele, przyrządy. Małe azjatyckie twarze albo ogromne rosyjskie, o białych oczach. Bryczką jeżdżą

8 Zygmunt Kmita (1976-1942), inżynier, działacz społeczny i polityczny, wolnomularz. W 1919 r. był współzałożycielem, potem wieloletnim dyrektorem Związku Polskich Stowarzyszeń Spożywców „Społem”.

9 Cytaty z listów Marii Dąbrowskiej i Anny Kowalskiej opatrzono w tym artykule inicjałem oraz datą listu. 
komandirsze $e^{\text {Io }}$, babska wyfutrzone, odęte, $\mathrm{z}$ noskami jak kartofelek na twarzy jak tyłek ogromnej (A. K., I2 XII I945).

Także Warszawa pierwszych powojennych miesięcy była miejscem trudnym do życia. Niezwykle ostre są powierzane listom oceny rzeczywistości społecznej po I945 roku. Opisy pustych półek, sposobów zdobywania żywności i przedmiotów codziennego użytku przewijają się przez całą korespondencję nie tylko wojennych, ale i pierwszych powojennych lat. Korespondentki pisały często (zwłaszcza autorka Ludzi stamtą) o nieznośnej atmosferze życia w kraju. Z okazji święta 22 Lipca Dąbrowska dzieliła się refleksją:

》Ten naród został oduczony radości. Święto jest bez święta, wesołości, bez wesela - wszystko pusta skorupa, z której wypełzło, wyciekło, z której uschło życie. Życie jest tylko w pracy - gwałtownej, namiętnej, żarliwej, nieustającej pracy niewolnika, wznoszącego być może nawet - piramidy (M. D., 22-23 VII I948).

Mając świadomość, że listy ich mogą być kontrolowane, mimo to relacjonowały absurdy ustroju, jak Kowalska opisująca reakcje chłopów na planowane wprowadzenie kołchozów oraz widoczną niechęć społeczeństwa do Związku Radzieckiego.

\Mowa w sprawie kołchozów na wszystkich rzuciła nowy cień zmęczenia. Wawa ${ }^{\text {II }}$ opowiada o sichowskich ${ }^{\mathrm{I} 2}$ mowach oratio recta do chłopów. Kiedy mówca zachwalający, „jak to ślicznie wieś wygląda, kiedy na wiosnę jeden traktor orze wspólną ziemię" - zapytał, co na to słuchacze, jeden przemówił: „gównoś nam położył pod nos i pytasz czy pachnie, a my ci mówimy - śmierdzi”. - Gospodarz, kt[óry] wrócił z zesłania, zabił derkami okno od wschodu. Byłby to dobry efekt sceniczny w 5 akcie (A. K., I9 VII i948).

Dąbrowską najbardziej interesowali ludzie i rozmowy z nimi, które streszczała Kowalskiej. Najtrudniejszym jednak problemem, z jakim musiała zmierzyć się w tym czasie, była sprawa śmierci jej siostry, Jadwigi Szumskiej, którą - wychodząc

10 Komandirsze - żony dowódców.

11 Wawa - Władysława Jakubas (1903-1987), opiekunka do dzieci, pracowała w przedszkolach i domach prywatnych, m.in. jako niania córki Kowalskich.

12 Sichów - wieś w województwie dolnośląskim, w której mieszkała rodzina Kowalskiej i gdzie pisarka przebywała od marca do kwietnia $1944 \mathrm{r}$. 
po kapitulacji powstania z Warszawy - pozostawiła ranną w szpitalu. Powierzała tę traumę Kowalskiej, od niej jednej oczekując słów pocieszenia.

\Jadzia ściga mnie wszędzie. [...] Kiedy ktoś mówi o Jej śmierci, omdlewam wewnętrznie z oczekiwania, że mnie o coś oskarży. Samo to, że osoba, co ją grzebała, przez rok przeszło nie odzywała się do mnie, wydaje mi się wyrokiem potępienia (M. D., I9 XI 1945);

Tylko Ty jedna umiałaś rozpraszać tę straszną chmurę, bez Ciebie potykam się ciągle o ten grób (M. D., 20 XI 1945).

Kowalska odpowiadała, choć w niżej cytowanych słowach trudno doszukać się nuty pocieszenia.

\section{1) Kochana,czy nie możesz z pokorą przyjąć Twojej w in y? To szamotanie się jest innym gatunkiem zła, a nadto jest zwy- kłą nieopanowaną psychozą, której nie zwalczasz (A. K., 24 XI 1945).}

Przez dłuższy czas (do połowy 1948 roku, gdy zorientowały się, że ich listy są otwierane przez cenzurę) bez zahamowań pisały o wojennych i powojennych losach przyjaciól i znajomych, np. o Marii ${ }^{13}$, żonie prof. Stanisława Kulczyńskiego.

\section{\Obecność Kulczyńskiej jest błogosławiona, ona jest tak rozkosznie trywialna, ale to z chęci pomocy. Na wszystko zaradzi, wszystkich zna, a za przyjaciół w ogień by poszła. Ją wsypał b[yły] delegat lw[ow- ski] Adam Ostrowski ${ }^{\text {I4 }}$, obecny poseł w Szwecji. Voilà. Wielu innych}

13 Maria Kulczyńska z d. Lang (1902-1982), znajoma Kowalskiej ze Lwowa, żona Stanisława Kulczyńskiego (1895-1975), profesora systematyki i morfologii roślin. W czasie okupacji razem z Kowalską prowadziła cukiernię. Współpracowała z konspiracyjnym pismem „Wytrwamy”, należała do lwowskiej Okręgowej Delegatury Rządu. Została aresztowana przez NKWD w nocy z 8 na 9 stycznia 1945 r. i zesłana do Krasnodonu (Donbas), gdzie pracowała w kopalni węgla. Została zwolniona 14 września 1945 r. wraz z innymi 23 osobami, najprawdopodobniej na skutek interwencji u Bolesława Bieruta kilkudziesięciu wybitnych naukowców polskich. Po powrocie do Polski zamieszkała z mężem we Wrocławiu. Napisała wspomnienia wojenne Lwów - Donbas 1945 (1988).

14 Adam Ostrowski (1911-1977), prawnik. Był asystentem w katedrze teorii prawa Uniwersytetu Jana Kazimierza we Lwowie i pełnomocnikiem do spraw młodzieży ówczesnego rektora Stanisława Kulczyńskiego. W okresie pierwszej okupacji sowieckiej (1939-1941) protestował publicznie przeciwko ukrainizacji uniwersytetu, za co został zwolniony. Od marca 1944 r. był Okręgowym delegatem Rządu RP we Lwowie. Po ponownym zajęciu Lwowa przez Rosjan został w sierpniu 1944 r. roku aresztowany. Od stycznia $1945 \mathrm{r}$. był zastępcą kierownika ministerstwa administracji publicznej PKWN, w lutym 1945 r. wojewodą krakowskim, następnie ambasadorem w Szwecji, a od 1948 r. w Rzymie. Po powrocie do kraju od 1950 r. pracował w Komitecie do spraw Radiofonii; w latach 1954-1967 był dyrektorem PIW-u. 
wsypanych dotąd siedzi na Eąckiego ${ }^{\mathrm{I5}}$. Między nimi profesor prawa $\operatorname{Pazdro}^{\text {I6 }}$ (A. K., II XII 1945).

Zwierzały się sobie ze wszystkiego, co było dla nich ważne, co je poruszało, co przeżyły. Na pozostałych obszarach problematyki intymności tej korespondencji lokują się relacje i refleksje związane z osobami Jerzego Kowalskiego i Stanisława Stempowskiego, wyznania dotyczące rodziny, sądy o przyjaciołach i znajomych, a nawet obszerne cytaty z ich listów. Swoiście intymny charakter mają nawet opisy otaczającej przyrody, oddające chwilowy nastrój piszącej, a także - nieprzeznaczone wszak dla oczu innych czytelników - relacje z wydarzeń życia społecznego i politycznego. Pojęcie intymności wykracza tu poza sferę związku i uczuć mu towarzyszących. Obejmuje również te rejony, które - choć związane z życiem zawodowym czy towarzyskim - kryją wiedzę o pisarzu ukrywaną przez niego, nieujawnianą publicznie, w tym jego wyraziste sądy o środowisku. Skrywany związek, który w I943 roku połączył pisarki, wyznacza główny, ale nie jedyny poziom intymności ich obszernej korespondencji. Obie szczodrze przekazywały sobie plotki o kolegach po piórze i znajomych, można przypuszczać, że z przekonaniem, iż wiedza ta nie wyjdzie poza karty ich listów. To zaufanie należy traktować jako specyficzną formę nie tylko porozumienia, ale też swoistej intymności, która pozwalała im formułować uwagi nie zawsze stosowne. Oto w jaki sposób Dąbrowska relacjonowała swój pobyt w Łodzi:

\ potkałam Kotta. Powiedział, że Sandauer ${ }^{17}$ wyjechał do Francji i że nie wróci. Ma jakoby zostać pisarzem francuskim. Tłumaczy na francuski swoje rzeczy i nową powieść pisze już po francusku. Kott powiedział: „Przecież więcej warto być pisarzem francuskim niż polskim. Należy, jak mówi pan Jerzy St[empowski] $]^{18}$, pisać w języku da nej cywilizacji. A tą jest jeszcze zawsze cywilizacja francuska”. Żydom, jak widać, i takie stanowisko uchodzi (M. D. 7 II 1948).

15 W latach 1939-1941 przy ul. Łąckiego we Lwowie mieścił się areszt na 1500 osób, przyległy budynek zajmowało NKWD, a w latach 1944-1946 znajdował się tam Wydział Śledczy i Areszt Śledczy NKWD.

16 Pisarka myliła się co do losów Zbigniewa Pazdry (1873-1939), prawnika, ekonomisty, w latach 1922-1934 (z przerwami) dziekana Wydziału Prawa Uniwersytetu Jana Kazimierza. Zginął we Lwowie 13 września 1939 r. w wyniku wybuchu bomby.

17 Artur Sandauer (1913-1989), krytyk literacki, eseista, tłumacz, od 1974 r. był profesorem Uniwersytetu Warszawskiego. W latach 1946-1948 przebywał w Paryżu jako korespondent „Odrodzenia”, a po powrocie do kraju pracował w redakcji tego pisma.

18 Jerzy Stempowski, pseud. Paweł Hostowiec (1894-1969), syn Stanisława, eseista i krytyk literacki. We wrześniu 1939 r. przedostał się na Węgry, od 1940 r. mieszkał w Szwajcarii. Od 1946 współpracował z paryską „Kulturą”. 
Pisarka chętnie udostępniała Kowalskiej treść listów Jerzego Stempowskiego, pisanych do ojca, Stanisława (nie wiadomo, czy za jego zgodą). W grudniu 1945 roku zacytowała niemal cały jego list, w którym opisywał swoje przeżycia z roku I939, gdy przy próbie przedostania się przez granicę zapadł na zapalenie płuc i bliski śmierci chronił się przez dłuższy czas w chacie przemytników. Świat swoich przeżyć i emocji obie korespondentki wzbogacały więc cudzymi losami, przeżyciami i refleksjami. Ich listy przez dłuższy czas były jak soczewki, w których skupiały się obrazy Polski lat okupacji i pierwszego okresu powojennego, nawet wtedy, gdy autorki niektóre informacje przekazywały szyfrem, zrozumiałym tylko dla nich. Ale nie stroniły też od przekazywania sobie plotek o intymnych sprawach członków rodziny i przyjaciól, m.in. Jerzego Stempowskiego:

\section{\ dowiedziałam się o osobliwie perwersyjnych gustach naszego wspa- niałego myśliciela. [...] Co prawda już p. Stanisław kiedyś mi mówił, że on może się kochać tylko w osobach starszych i chorych, a i ta dra- matyczna Rosjanka jego młodości miała pod pięćdziesiątkę i chromała na obie nogi (M. D., 25 X 1948).}

Dąbrowska z pełnym zaufaniem powierzała przyjaciółce informacje o swoich kontaktach $z$ dygnitarzami władzy ludowej, m.in. o spotkaniach z Jerzym Borejszą, jego pomocy w sprawie znalezienia pracy dla jej brata ${ }^{19}$, czy interwencji w urzędzie skarbowym $z$ racji rzekomo niezapłaconego podatku. Kiedy indziej pisała (nie bez poczucia dumy) o względach wobec swoje osoby:

\section{\B Borejsza ${ }^{20}$ rozwinął wszystkie czary „kuszenia na pustyni”. Trudno Ci opowiedzieć, do jakiego stopnia o mnie zabiegają. [...] Bierut pytał mnie - czy to prawda, że pani D[ąbrowska] jest $\mathrm{z}$ nas niezadowolona? W Prez[ydium] Rady Ministrów pytali: czy aby pani D[ąbrowska]}

19 Bogumił Szumski (Boguś) (1896-1957), najmłodszy z rodzeństwa Marii Dąbrowskiej, kawalerzysta, podpułkownik. W czasie pierwszej wojny światowej walczył w 1. Pułku Ułanów Legionów Polskich Władysława Beliny-Prażmowskiego. W okresie międzywojennym był oficerem zawodowym. W czasie drugiej wojny światowej dowodził 24. Pułkiem Ułanów Pancernych w dywizji gen. Stanisława Maczka w Wielkiej Brytanii, następnie jako dowódca brygady do zakończenia wojny prowadził obóz uzupełnień dywizji w Szkocji. Do kraju powrócił w 1946 r. i krótko pozostawał w wojsku. Następnie pracował jako urzędnik, m.in. w Powszechnym Zakładzie Ubezpieczeń Wzajemnych.

20 Jerzy Borejsza (1905-1952), wydawca, publicysta, działacz komunistyczny, od 1929 r. w KPP, współpracownik m.in. pism „Sygnały”, „Czarno na Białym”, „Robotnik”. W latach 1939-1940 przebywał we Lwowie, gdzie był dyrektorem Ossolineum. W 1944 założył tygodnik „Odrodzenie”, którego redakcję powierzył Karolowi Kurylukowi. Był organizatorem i prezesem Spółdzielni Wydawniczo-Oświatowej „Czytelnik”, a w 1948 r. inicjatorem i sekretarzem Światowego Kongresu Intelektualistów w Obronie Pokoju we Wrocławiu. 
weźmie udział w tym kongresie Międzynarodowym we Wrocławiu? itd. Wyszłam oszołomiona (M. D., 5 V I948).

Kowalska, bardziej sceptyczna i ostrożna, była nieufna wobec nowych tendencji w polityce kulturalnej i oczekiwań władz wobec literatów. Pisała: „Przypuszczam, że potępienie eklektyzmu w literaturze odbije się niebawem w polityce wydawniczej. Jak reumatyka przed burzą, bolą mnie kości duchowe" (A. K., 7 IX I948). Ich sądy o polskiej literaturze współczesnej były jednak równie ostre i bezkompromisowe. O Tadeuszu Borowskim i jego Pożegnaniu z Mariq i Kamiennym świecie Dąbrowska napisała:

\utalentowany, ale rodzaj wizji artystycznej obrzydliwy, postawa życiowa odrażająca, klimat utworu cuchnący. To polski Céline, o tyle gorszy, że Céline miał jeszcze jakiś rodzaj tkliwości dla jakichś typów, współczucia dla jakichś sytuacji życiowych. Okrucieństwo Borowskiego jest małym okrucieństwem złego dziecka, znęcającego się nad wszystkim, co słabe (M. D., Io XII I948).

Mimo tej niemal demonstracyjnej otwartości listów, pisarki liczyły się z faktem, że niepowołane osoby systematycznie je przeglądają. Liczne sygnały w ich korespondencji wskazują, że najciekawsze wątki zaczęły pozostawiać do osobistego spotkania: „Wiele trosk lokalnych, które pomijam w listach”(A. K., 28 VII 1948)”; „Wczoraj był Boguś - ten opowiadał rzeczy nadzwyczaj ciekawe” (M. D., 8 VIII 1948). Świadomość kontroli powodowała, że zmienił się charakter korespondencji. Jest to rodzaj granicy postawionej intymnej rozmowie, niezamierzonej przez autorki listów, wymuszonej przez okoliczności zewnętrzne, powodującej, że listy traciły na atrakcyjności, stawały się bardziej „,znakiem życia” niż pożądaną przez adresatkę informacją.

\W tych dniach dowiedziałam się o poczcie rzeczy, które czynią zrozumiałym, czemu nasze listy idą po siedem dni czasem. Musimy, niestety odmówić sobie rozkoszy szczerego komunikowania myśli, nie dlatego, abyśmy miały coś niecenzuralnego do pisania, ale że dojmująco przykra jest myśl o ślinieniu naszych słów okiem urzędowej obleśnej ciekawości (M. D., 2 V I948).

Blok korespondencji Maria Dąbrowska - Anna Kowalska dokumentuje złożony i niejednoznaczny problem intymności, jej poszanowania i przekraczania jej granic. W tle historii ich wspólnego życia kryje się problem wzajemnej (nie)wierności 
i lojalności, także wobec mężczyzn swojego domowego życia, a przede wszystkim sprawa Tuli ${ }^{2 \mathrm{I}}$, której narodziny nieodwracalnie zmieniły charakter związku i losy przyjaciółek. Nie obawiały się swojej miłości, nie wstydziły się jej, choć ukrywały ją przed otoczeniem, zwłaszcza przed najbliższymi, stosując najróżniejsze kamuflaże. Ta sekretna relacja, która je połączyła, co pewien czas wymuszała ograniczenia jawnej intymności, tak w kontaktach bezpośrednich, jak i w listach.

Widoczną cechą tej korespondencji jest narzucające się w lekturze napięcie psychiczne, wynikające z innego rozumienia swojej roli w tej przyjaźni, potem związku, a także z odmiennych predyspozycji psychicznych korespondentek, innego rozumienia właśnie „intymności” zarówno listów, jak przede wszystkim samej łączącej ich relacji. Wydaje się, że już u jej początku między przyjaciółkami powstało zasadnicze niedopowiedzenie, rzutujące na dalsze ich losy. Anna, inicjatorka relacji, od początku istnienia związku próbowała wyznaczyć jego granice, oddzielające jej i Marii sfery życia rodzinnego, którego nie zamierzała unieważniać ani nawet zmieniać; nie ukrywała też, że jedynie taka sytuacja jest dla niej do przyjęcia.

1) Pewna przyzwoitość nie pozwala mi mówić o różnych moich uczuciach, powiedzmy, zadziwienia, na taką niedomyślność. Więcej się boję o siebie, bo chcę być z Tobą. To brzydko i nielojalnie napisałam. Bo to wszystko moja wina. I Jerzy jest nie tylko sto razy więcej wart, ale mnie więcej kocha niż ja jego i daje mi zupełną swobodę (A. K., I4-I5 IX I943).

Dlatego też Maria, przekonana o wyłączności ich związku, przeżyła szok, gdy złamawszy tabu niesięgania do cudzego diariusza, przewertowała bez zgody Anny jej notatki.

1) Przeczytałam Twój intymny dzienniczek. Nie wiem, czy sobie tego życzyłaś. Zrobiłam to. Ciężki wstrząs, jeżeli nie powiedzieć - cios. Dotąd nie mogę jeszcze ochłonąć. Ujawniona nagle prawda dwoistego pożycia, której się domyślałam, ale której nie chciałam przyjąć do świadomości, zobaczona raptem plastycznym widzeniem - oczywista (M. D., 27 III 1944).

Dość szybko Anna zorientowała się, że oto weszła w zawikłaną, pełną niejasności i sprzeczności relację, w której trudno jej będzie bronić swoich racji: 
\ Ty taka siebie niepewna, zmienna, kapryśna. Mówisz same rzeczy prawe, rzetelne, godziwe, wykładasz je jasno, nie cofasz się, nie cofasz się przed tym, co ktoś może odczuć, ale walisz wprost. I z całej tej prostoty, jasności, prawdomówności dla drugiego człowieka - niech wysłuchana będzie et altera pars ${ }^{22}$ - wynika kręta, niejasna, niewyraźna sprawa.Ty jasno myślisz i dlatego zdaje ci się, że jasno i jednoznacznie czujesz, ale nie wyobrażam sobie, aby łatwo można było znaleźć taki kształt sprzeczności, o ile chodzi o ciągłość uczuć - jak u ciebie (A. K., IO-II IX I943).

Wyrażona przez Annę niechęć do nadmiernej dosłowności wynikała tak z potrzeby wstrzemięźliwości słowa, jak i z poczucia, że zbytnia bezpośredniość w sprawach uczuć jest narracją destrukcyjną, raniącą i paradoksalnie - oddalającą od prawdy, zniechęcającą do związku. Jej listy nader często dalekie były w swojej formie od typowych wyznań miłosnych; relacjonowała swoje życie, sprawy, komentowała wydarzenia. Opór Marii wobec takiej formy kontaktu wynikał być może także z jej potrzeby nieustannej adoracji i akceptacji, do której przywykła w związku ze Stempowskim. Ta z jednej strony wstrzemięźliwość wyznań intymnych Anny, z drugiej dosłowność Marii - prowadziły do spięć i kolizji słownych. Inaczej postrzegały świat i swoje życie; na poziomie emocjonalnym świat Marii ostatecznie skurczył się do sprawy miłości; pisała:

\Przyszło mi dziś do głowy takie zdanie „powieściowe”: jedyną możliwą do przyjęcia postacią istnienia jest istnienie wspólne dwojga kochanków. Wszystko inne jest tylko udawaniem, że się żyje (M. D., I9 XII 1945).

Miała silną potrzebę nieustannego definiowania swojej i Anny sytuacji uczuciowej, stałego jej potwierdzania, uzasadniania, tak jakby słowa pisane znaczyły więcej niż rozmowy, spotkania oraz czyny. Było w tym też coś z ważenia racji obu stron, oceny stopnia zaangażowania w związek, a przede wszystkim - Dąbrowskiej poczucie ostateczności dokonanego wyboru, jego wyłączności.

\Dla mnie „być związaną z tobą” było tysiące razy rzeczą trudniejszą niż dla ciebie, wiesz dlaczego. U Ciebie to był naturalny wyraz twoich skłonności (o których słyszałam, jeszcze zanim cię poznałam, o któ- 
rych wiem zresztą z Grucórw ${ }^{23}$ ), ja tego penchant ${ }^{24}$ w tym stopniu nie miałam i z wyjątkiem jednego lwowskiego wypadku mogłam ulegać tylko tzw. „pozostawaniu pod urokiem” jakiejś kobiety. Ale z chwilą, kiedy przezwyciężyłam w sobie jakieś opory psychiczne czy obyczajowe, przywiązanie moje stało się ostateczne i wszechstronne (M. D., 2 I 1946).

Właśnie poczucie „ostateczności” tego emocjonalnego wyboru i całkowite podporządkowanie mu swojego życia spowodowało, że listy Dąbrowskiej na wieść o ciąży Kowalskiej nader często zamieniały się w „obelgi i insynuacje nieprzytomnej z rozpaczy miłości” (M. D., 2 I I946) czy „okropne i zhisteryzowane” (M. D., 3-4 V 1946). Po kilku latach, wobec nieustannych nieporozumień z Marią, Anna, nieskłonna do zanegowania swojego życia obok Jerzego Kowalskiego, musiała postawić sprawę jasno:

\Maryjko, jestem twoja. Nie w tym leży trudność, że cię przestanę kochać, ale w tym, że kochając ciebie sercem, duszą, ciałem, wyobraźnią, umysłem także, kocham J[erzego]. Bo to chyba najprostsze słowo. Wiesz, że po dwudziestu dwóch latach małżeństwa nie ma mowy o erotyzmie. Jerzy, kiedy mu powiedziałam, że jestem w ciąży, powiedział: „Musi ci być ciężko, że tak się stało teraz, kiedy już mnie nie kochasz". Nie jest tak, jak mówisz, że twoja miłość ożywiła moje stosunki z J[erzym]. Wolałabym, aby były ustały zupełnie. Nie, myśmy byli szczęśliwymi kochankami i szczęśliwymi ludźmi. I nasze życie było piękne. Jerzemu zawdzięczam wszystko, co umiem, wszystkie podróże. I jestem mu wdzięczna. Ty go znasz od najgorszej strony, ja go znam od najlepszej. Po tylu latach człowiek taki zmienia się w ojca, stryja, brata (A. K., 7 I I946).

Bez wątpienia obu kobietom intymny związek, który je połączył, jawił się jako życiowa komplikacja. Obie też miały potrzebę określenia swojego stosunku do miłości homoseksualnej, choć rzecz się już dokonała i nie wymagała w zasadzie tego rodzaju pisemnych deklaracji. W tym związku obie widziały przede wszystkim różnego rodzaju niebezpieczeństwa i przykre konsekwencje: uwikłania w sytuacje bez wyjścia, publiczne ujawnienie związku, ostracyzm środowiskowy, komplikacje w relacjach domowych. 
\ Drogeńka moja, ja nigdy nie uważałam miłości homoseksualnej za niższą, gorszą czy mniej szanowną. [...]. Jest prawdą, że nie mam w tym kierunku specjalnej predylekcji, ale nie dlatego, żebym to sądziła mniej „szanownym”. Może dlatego, że czuję taką miłość jako nieskończenie bardziej niebezpieczną i to we wszystkich znac z e n ia ch niebezpieczną, i prowadzącą w nieunikniony sposób, jak chyba przekonałaś się na nas, do sytuacji bez wyjścia (M. D., I6 I I946).

Kowalska oceniała to uczucie w szerszej, kulturowej perspektywie, o czym rozważnie pisała do przyjaciółki:
\Miłość nie jest rzeczą wstydliwą. Kochana, co za szczęście, że nie wstydzisz się miłości. Co za ulga! Miłość jest albo jej nie ma. Miłość homoseksualna, o ile nie jest kabotyństwem, ale po prostu jest, jest bardziej corrosif ${ }^{25}$, dręcząca, ale w niczym nie jest mniej ważna czy „szanowna”. [...] Mieszczaństwo nienawidzi miłości, od wieków. To jest zastanawiające, jakie to tabu (A. K., 2 I 1946).

Maria także miała świadomość łamania tabu, uważając, że upoważnia ją do tego tęsknota i cierpienie.
》 Kto się tak poczuł zlekceważony w miłości, jak ja się poczułam, mimo wszystko co prócz tego czuję, sam staje się jakiś lekceważący wszystko, a zwłaszcza to, co mu zdawało się tabu (M. D., I7 I 1946).

Obie były świadome, że prowadzą tajną grę z nieprzyjaznym otoczeniem, wymagającą dyskrecji. „Byłam i w listach dyskretna, liczyłam się z okolicznościami czasu, z możliwością ich wpadnięcia w niepowołane ręce, teraz mi już wszystko jedno" - pisała Dąbrowska (M. D., 2 I 1946). Kowalska natomiast pisała o cenie, jaką przyszło jej płacić za złamanie obyczajowego tabu: „Ty byłaś osobą, z którą się liczono oficjalnie, ale mnie nie oszczędzano" (A. K., I 1946). Annę krępowała zresztą obecność w życiu Marii Stanisława Stempowskiego, którego bardzo ceniła i któremu nie potrafiłaby zrobić przykrości, oczekiwała więc od przyjaciółki powściągliwości w rozmowach na swój temat. „Dla niego i tak to ciężki problem «od jego strony». Był b[ardzo] dobry dla mnie, ale ja się go boje” (A. K., 3-4 I 1946). Także dla Marii obecność w ich życiu codziennym obu towarzyszy życia stanowiło przeszkodę, odbierająca radość kochaniu. 
\Byłam nerwowa, paraliżowało mnie, że to wszystko się działo u boku St[anisława], niemal przez ścianę albo w sąsiedztwie J[erzego]. Tyś potrafiła o tym zapomnieć - ja nie, to cała moja wina - i to, że milczałam! (M. D., 3 I 1946).

O ile Anna miała jasność co do swojej relacji z mężem, dla Marii osoba Stanisława Stempowskiego stała się poważnym problemem. Zniknęło uczucie, którym darzyła go przed zawiązaniem relacji z Kowalską, pozostało jedynie przywiązanie; w jednym z listów napisała o nim: „Rekwizyt, sublokator, ceniony obiektywnie. Nic więcej” (M. D., I III I946). Wkrótce w listach do Anny Stanisław stanie się „panem Stanisławem". Wyjaśniała też:

\section{$\gg$ Jest prawdą, że uważam go za drogiego przyjaciela, że jestem do niego w jakiś nieważny sposób przyzwyczajona. Ale ja tylko i je- dynie boję się, aby przeze mnie nie umarł na serce. Poza tym nie tylko nie kocham go, ale przeważnie już nawet i nie lubię. Nie cierpię nawet tego rodzaju „sympatyczności”, którą on wszyst- kich czaruje, choć obiektywnie uważam to za wielką zaletę życiową (M. D., I2 I I946).}

Takie doświadczenia wymuszały dyskrecję, zaburzały naturalny tok związku, paraliżowały spontaniczność spotkań. Te ograniczenia obie bez końca próbowały opisać, wyjaśnić, wytłumaczyć. List stawał się więc komentarzem do sytuacji zaistniałych w przeszłości, jednocześnie jednak - poddany wymogom dyskrecji - sam wymagał dodatkowych wyjaśnień. Stąd „ciągła jakaś potrzeba korekty tego, co się powiedziało. Jakiś strach przed sfałszowaniem"(A. K., 5 I 1946). Prowadziło to do wielu przykrych nieporozumień między przyjaciółkami; zwłaszcza Dąbrowska, zraniona i podejrzliwa, celowała w doszukiwaniu się w listach Kowalskiej zgoła innych znaczeń niż zamierzone. Mimo to pisały stale, Dąbrowska czasem po kilka-kilkanaście listów dziennie, wielu z nich nie wysyłały, niektóre podobno niszczyły.

Granice intymności, wyznaczone przez same korespondentki, $w$ ich listach są płynne i zmienne. Autorki raz je twardo wyznaczały, innym razem usuwały, w zależności od chwilowego nastroju lub zmiany sytuacji życiowej. Wyrażały oczekiwania ze sobą sprzeczne, żądania niemożliwe do spełnienia, co sprzyjało neurastenicznym reakcjom i skutkowało brakiem kontroli nad pisanym słowem, a wszystko to zmieniało optykę intymności. Siła zaangażowania w związek z Kowalską była dla Dąbrowskiej wyniszczająca - pisała głównie listy do Anny, obsesyjnie i bezustannie, jej twórczość literacka niemal zamarła. Skupiona na intymności Dąbrowska wypaliła się jako twórca, choć wcześniej żyła w przekonaniu, że może tworzyć 
tylko wówczas, gdy kocha. Wypatrywała niecierpliwie listów Anny, ale swoje pisała i wysyłała, nie czekając na otrzymanie przesyłki od przyjaciółki.

》 Ja w ogóle nie mogę nic robić, tylko piszę do ciebie - wciąż, wciąż, jedną dziesiątą tego, co piszę, wysyłam. Nie żyć z tobą, nie dzielić się z tobą każdym najmniejszym skrawkiem życia, choćby listem, jakaż to klęska przeraźliwa (M. D., 3 I I946).

Także Kowalska odczuwała narastający przymus pisania, listy zaś przestawały pełnić funkcję komunikatu na piśmie, a stawały się literackim zapisem nastrojów, wrażeń, uczuć, wspomnień, słów niewypowiedzianych w bezpośredniej rozmowie, ujawniały sytuacje nienazwane w trakcie osobistych kontaktów.

\Wybacz rozwiązłość moich ostatnich listów. Milczałam trzy lata niech mówię! [...] Ja zawsze w życiu byłam taka milcząca na ten temat. Ja umiem mówić tylko, kiedy piszę. Tak było nawet z Marianem $^{26}$, i może dlatego on też wyobrażał sobie czasem, że go za mało kocham (M. D., 2 I 1946).

Maria wyobrażała sobie, że i Anna poddana jest podobnym ograniczeniom; pisała: „mnóstwo rzeczy było dla ciebie nie możliwe do powiedzenia” (M. D., 2 I I946).

Wiele listów jest przesyconych dosłowną zmysłowością, jakby miały zastąpić niedostępną w danej chwili pieszczotę, udowodnić i podtrzymać uczucie, przekonać o jego wyjątkowości. Dotyczy to zwłaszcza tych okresów ich wspólnego życia, gdy długo nie mogły się widzieć, zwłaszcza czas przed przyjściem na świat Tuli.

\Moje święte ciało, od trzech lat czekam na Ciebie, bez przerwy, z napięciem, nienasycenie. Każde miejsce na twoim ciele to inna, osobna radość, przyjemność. Ty dajesz mi rozkosz. Nie mogłabym Cię kochać, nie podziwiając twojej duchowej siły, nie uwielbiając Cię jako wspaniałe duchowe zjawisko, ale twoje ciało ma dla mnie swoje tajemnice, których nie potrafię powiedzieć, ale które chłonę całą skórą, całą gorączką krwi. [...] Tyś jest moją miłością (A. K., 2 I 1946).

26 Marian Dąbrowski (1882-1925), major Wojska Polskiego, publicysta historyczny, wolnomularz, młodszy brat Józefa Dąbrowskiego (Grabca), historyka, publicysty, działacza politycznego, od $1911 \mathrm{r}$. mąż Marii Dąbrowskiej. 
Obecny czytelnik nie może mieć pewności, czy tak intymne wyznanie jest całkiem szczere, czy też może jest pisane z potrzeby chwili, aby ukoić rozpacz przyjaciółki, udowodnić jej to, w co przestała wierzyć, zraniona zdradą kochanki? Wszak Dąbrowska uważała, że rozłąka w „takich okolicznościach” jest „okrutnym wrogiem bliskości” (M. D., 23 V 1946). Przyszłe macierzyństwo Kowalskiej przeżyła jako akt niewyobrażalnej zdrady, pogwałcenie wszelkich zasad wierności, lojalności, miłości. Kochając, wymagała wyłączności, żądała od Anny porzucenia męża, a nawet dziecka. Tego otrzymać nie mogła, Anna bowiem kochała oboje: męża i Marię, a narodziny Tuli zburzyło jej porządek nie tylko życia, ale i odczuwania.

Granice intymności wyznaczone przez Annę Kowalską po tym, gdy ujawniła Dąbrowskiej swoje przyszłe macierzyństwo, objawiają się widoczną powściągliwością jej listów. Pisze rzadziej, są to raczej zapiski, zrównoważone refleksje i rozważania, pisane typowym dla niej „stylem metaforycznego-przypowieściowym” (M. D., ıo IX 1943), mające uspokoić zarówno ją, jak i przyjaciółkę. Rzadko pisze dramatycznie czy stanowczo. Zasadniczą rolę odgrywa tu oczywiście odmienność psychiki obu autorek, różny bagaż pierwiastka neurastenicznego cechującego Marię i swoistego stoicyzmu u Anny, ale przede wszystkim - inny stosunek do faktu przyszłych narodzin dziecka. Dąbrowską, przytłoczoną tą wiadomością, długo nie interesował świat wokół niej, tonęła w miłości i rozpaczy, Anna - przyjąwszy za oczywistość swoją nową sytuację życiową, relacjonowała toczące się wokół życie domu i rodziny, sprawy środowiska wrocławskiego $z$ całym jego powojennym skomplikowaniem, pochylała się nad kwiatami na grządkach, przybłąkanym kociakiem, interesowała się problemami Wrocławia, losem służących Niemek. Ale tė̇ „śmiertelnie nerwowo i psychicznie wyczerpana przeżywaniem tych samych myśli i uczuć od tylu miesięcy" zapadała w wielodniowe milczenie, które określała jako „otępienie” (A. K., I4 I I946); odgradzała się nim od przyjaciółki, łamiąc obietnice intymnych zwierzeń. Zmęczona wyznaniami, listy zamieniała w kroniki swojego życia codziennego, ograniczając intymne wyznania do drobnych wzmianek.

W styczniu 1946 roku Maria zaczęła spisywać „kronikę niewierności” Anny, zestawiając swoje wspomnienia i podejrzenia z zapiskami dzienników kochanki, które potajemnie przeczytała i z którego wypisała niepokojące ją stwierdzenia, np. zdanie „Męczy mnie być raz z jednym, raz z drugim”. W tym najściślejszym ze związków taka niedyskrecja była oczywistym przekroczeniem granic zaufania. Podobnie wątpliwą decyzją wydaje się danie Annie do czytania listów Mariana Dąbrowskiego do żony; Kowalska nie odmówiła, potem jednak napisała: „Te dwie noce, kiedy czytałam listy twego męża, były torturą"(A. K., I5 I 1946) ${ }^{27}$. Choć Anna

27 Listy Dąbrowskiej do męża zob. Ich noce i dnie. Korespondencja Marii i Mariana Dąbrowskich 1909-1925, wstęp i oprac. E. Głębicka, Warszawa 2005. 
z przykrością i zawodem przyjęła fakt czytania jej dziennika bez pytania o zgodę, to jednak spisywanie przez Marię w dzienniku owej „kroniki niedoli” czy „niewierności” zostało przez nią odebrane jako postawienie tamy intymności i odrzucenie przez przyjaciółkę szczerej listowej rozmowy ${ }^{28}$ :

\Nagle piszesz jak do obcego człowieka. Dlaczego? Oblewasz mnie gorącą, to lodowatą wodą. Już sama nie wiem, co pisać, jak pisać, czego nie pisać. Naprawdę, jestem niespokojna i przerażona. Dlaczego zaczęłaś pisać dziennik, który mnie pozbawia słów, których nie czytam? Maryjko, Maryjko, zlituj się nade mną (A. K., 3 IX I946).

Także Dąbrowska miała poczucie, że szczerość w intymnej korespondencji może stać się - paradoksalnie - zagrożeniem dla związku.
\Siedzę i myślę, czy pisać wszystko, co myślę. Każdy list bardziej szczery jest jakimś ryzykiem, po którym chodzę przerażona, bo nie wiem, jak zareagujesz. Reakcje nawet najbliższych ludzi są tak nieprzewidziane, cóż mówić o tych, co są tylko „pół-nasi”. Ale przecie pisać wszystko wydaje się jedynie wartym życia. I przecież chyba teraz można, skoro „nie buntujemy się już”, tylko piszemy epicką kronikę naszych we- wnętrznych zdarzeń (w tej chwili przemyka mi przez myśl: „Twoim wewnętrznym zdarzeniem będzie wkrótce ruch dziecka”) (M. D., I7 I 1946).

Ton korespondencji Dąbrowskiej i Kowalskiej przypomina czasem pole bitwy, a potem ostrożne negocjacje pokojowe i kompromisy, tym trudniejsze, gdy jedna strona żądała wyłączności, druga zaś wyznaczała związkowi granice, oczekując ich nieprzekraczania.

\section{Sprawa Tuli}

Wobec kobiecych dolegliwości Anny, Maria miała przekonanie, że ciąża byłaby najlepszym lekarstwem na nie. „Jestem zrozpaczona, że możesz go chcieć poszukać i masz ku temu prawo” - pisała (M. D., ıo IX I943), nie spodziewając się, że teoretycznie porusza problem, który postawi ją wkrótce wobec poważnej próby

28 Lektura dzienników Dąbrowskiej i Kowalskiej pokazuje, że obie notowały tam opinie i refleksje, odmienne od formułowanych w listach. 
życiowej. W grudniu I945 roku dowiedziała się, że przyjaciółka zaszła w ciążę; była to sytuacja, która zdominowała treść listów Marii aż do końca maja I946 roku. Ich lektura wskazuje, że oczekiwanie na przyjście na świat dziecka Kowalskich było dla Dąbrowskiej egzaminem moralnym, któremu w dużej mierze nie sprostała. Często, zbyt często przekraczała granicę dopuszczalną nawet w tak bliskich relacjach. Wprawdzie Anna, zaskoczona późną ciążą, nie demonstrowała radości z tego powodu, ale - wybrała macierzyństwo, choć (bezpodstawnie) nie spodziewała się pokochać dziecka, gdy się urodzi. Maria jeszcze nienarodzone dziecko traktowała jako zagrożenie związku, który był ostatnim, najważniejszym sensem jej życia. Dąbrowska, często pisząc pod wpływem alkoholu, przekraczała granicę wyznania intymnego w sposób, który nie poddaje się komentarzowi, a Kowalską stawiał wobec konieczności zmierzenia się ze słowami przyjaciółki.

\section{\Nie, nie, nie, opowiadasz dramat $\mathrm{z}$ innego teatru. Kiedy przeczytałam, jak życzysz śmierci temu dziecku, wprost zamarłam z przerażenia. Wiedziałam, że to musi być przez ciebie powiedziane, ale to straszne (A. K., 3-4 I 1946).}

Wprawdzie już w kolejnym liście Dąbrowska swoje poprzednie drastyczne epistoły nazwała „chamskimi, ordynarnymi i zgoła niepoczytalnymi”, pisanymi jakby dostała „jakichś mózgowych wymiotów trucizny słowa” (M. D., 7 I I946), ale Kowalska przecież je przeczytała. Jednak również i ona zaparła się siebie i przekroczyła pewną granicę, także etyczną, gdy w kolejnym liście używała praktycznych argumentów, tłumaczących ją z decyzji urodzenia dziecka.

Sprawa Tuli i otwartość w wymianie myśli ujawnia czasem szokującą czytelnika treść rozmów w czasie spotkań, do których przyjaciółki wracają w listach.
\W lutym mówiłaś: „Ja oddam dziecko jemu i będę miała spokój. To mi się opłaci”. Jakoś tak głupio czepiłam się tego, że to będzie jego dziec- ko - jemu pour son bien ${ }^{29}$ urodzone i oddane. I oto dziś w owych dwu listach już drwisz ze mnie, że mówię o „rodzeniu dzieci mężowi”. Już wołasz, że dziecko rodzi się sobie i dla siebie (M. D., 23 IV 1946).

Śmiertelna choroba Jerzego Kowalskiego i świadomość dramatyzmu sytuacji nie powstrzymała Dąbrowskiej przed nieustannym analizowaniem grzechu macierzyństwa przyjaciółki: 
\Myślałam, że nie kochasz dziecka, teraz już wiem, że je kochasz i będziesz kochać coraz bardziej - nudziło cię tylko niemowlę. Ach, kochana - jak to więc $\mathrm{z}$ tobą jest? Co z tobą jest? Moje ty kochanie, tak bym chciała wziąć Cię na ręce, utulić, ukołysać, o s w o b o d zi ć, tak - oswobodzić, jak zaklętą w złej bajce (M. D., 20 X I947).

Mamy do czynienia ze swego rodzaju niejednoznacznością wymogów intymności tej korespondencji. Granice związku i granice wyznania, które korespondentki stawiają, są zmienne, niestabilne, nie zawsze wzajemnie rozumiane czy akceptowane. Najbardziej drażliwe refleksje obie zapisują wyłącznie w dziennikach, choć jednocześnie apelują o szczerość. „Pisz do mnie i pisz mi wszystko” - prosiła Dąbrowska, równocześnie dopisując na liście ironiczną uwagę: „czytaj to jak złą literaturę" (M. D., 3 I I946). W chwilach spokoju i rozwagi miała świadomość, że listy jej - przepełnione słowami krzywdy, „krzyczane”, w których nieustannie, obsesyjnie wracała do spraw dawno wyjaśnionych - bywały nie tylko trudne do przyjęcia, ale wręcz lokowały się na poziomie marnej literatury. Czytanie ich w ten sposób dawałoby Annie możność wzniesienia się ponad dokuczliwy ton wielu listów Marii, stanowiło sposób na oswojenie zbyt drastycznych sformułowań i niemożliwych do spełnienia żądań, uwalniało czystą intymność od trucizny oskarżeń i pomówień. Ale też - wprowadziło poczucie koniecznej ostrożności, ułatwiającej unikanie konfliktów, gdyż szczerość stawała się pułapką.

》Skarżysz się, że nie odpowiadam na listy. Nie wiem dokładnie, o jaki szczegół Ci chodzi. Między nami leży przepaść, obchodzę ją dalekim kręgiem - co sprawia, że nawet niewinne tematy omijam ze strachu. [...] Musimy mieć dużo cierpliwości i wyrozumieć sobie nawzajem naszą okropność. Bo niektóre listy Twoje był y straszne, odebrały mi jakoś uczucie godności - bez której zbyt ciężko, zbyt niebezpiecznie istnieć. A wiem, jak się sprawa ma z Tobą (A. K., 27-29 X 1946).

\section{„ZNISZCZ MOJE WSZYSTKIE LISTY”}

W odniesieniu do listów prywatnych, pierwotnie nieprzeznaczonych dla innego czytelnika niż adresat, nie ma podstaw oczekiwać od korespondentów wytyczania granic wyznaniom intymnym, nie jest też uzasadnione punktowanie miejsc, w których - zdaniem obcego odbiorcy - takie granice zostały na różnych poziomach przekroczone. Całe partie korespondencji Dąbrowska-Kowalska są w istocie przykładami przekraczania wielu tematów tabu, do czego przecież obie piszące 
miały oczywiste prawo. Tylko one mogły sobie wzajemnie takie granice wyznania intymnego ustalać i - czyniły to wielokrotnie. „Maciusiu kochany, palę list za listem”(A. K., 29 III 1944); „Dziś zniszczyłam kilkadziesiąt listów niewysłanych do Ciebie. Cztery z nich zachowałam, może Ci je kiedyś pokażę" (M. D., 26 I I946). Czytelnik nie ma pewności, czy czyta prawdę, czy też może ma do czynienia z figurami retorycznymi, rodzajem literackiej gry z intymnością. Nie sposób ustalić (wobec braku wielu kopert), które z zachowanych listów zostały napisane, ale niewysłane, być może wiele $\mathrm{z}$ nich korespondentki przeczytały znacznie później. Spora liczba listów zaginęła (może zostały zniszczone?). W tak niejasnej sytuacji otrzymujemy jedynie odpowiedź na pytanie, skąd tyle w nich powtórzeń, sprawiających wrażenie obsesyjności, co potwierdziła sama Dąbrowska, pisząc: „Ot, i druga noc schodzi na paraniu się z paru zdaniami Twego listu” (M. D., 7 XII 1945). Podobne deklaracje znajdujemy w listach Kowalskiej. Znaczące jest jej stwierdzenie, że nie wysłała jakichś listów, ponieważ - pod wpływem impulsu zawarła w nich twardą prawdę.

Właściwie nie wiadomo, jak traktować prośby Dąbrowskiej o zniszczenie jej listów przez Kowalską; sama - wbrew deklaracjom - przechowywała skrzętnie każdy skrawek papieru przysłany przez Annę, w tym też swoje niewysłane listy. Można przypuścić, że słowa takie to minoderia, a może rozpaczliwe wołanie o uwagę.

\section{\Kochana, zniszcz moje wszystkie listy, jak i ja Twoje będę niszczyć. Wolałabym, żebyś ekspres mój miała w sercu niż w medalionie. Nie piszemy przecie na to, aby ludzie się tym kiedyś bawili - tylko dla siebie (M. D., I2 I I946).}

Żądanie Marii, by Anna spaliła otrzymane od niej listy, ale jednocześnie świadomość, że Anna je przeczyta, wydaje się rodzajem przewrotnej gry z intymnością wyznań, tak jak i niszczenie przez Dąbrowską w czasie pobytu we Wrocławiu swoich listów wykradzionych ze schowka, w którym przechowywała je Kowalska. Przymus wyznania stanął tu w parze ze świadomością jego niestosowności, potrzebą kontroli, ale może też potrzebą usunięcia pisanego świadectwa swoich nierozważnych wyznań i żądań.

Dla Kowalskiej w tym związku najważniejsza była rozmowa; był to ten wymiar intymności i porozumienia, który ceniła najwyżej. „Jest to może najbardziej udana forma naszego związku. Kto wie, jest to może sercem i treścią naszej miłości” - pisała (A. K., 26 IV I946). Takie postawienie sprawy była wyraźną próbą uporządkowania relacji, postawieniem granicy, choć list jest także formą rozmowy. Chodziło więc raczej o danie odporu pomysłom Marii rozbicia rodziny Anny, wspólnego 
zamieszkania gdzieś daleko, z dala od zobowiązań wobec Stanisława, a zwłaszcza Jerzego i dziecka. Rozmowa za pośrednictwem listu jawiła się Dąbrowskiej jako „uboga forma obcowania”, bo „mimo tej orgii słów” miała poczucie niezrozumienia. „Czyżby prawdą były słowa Conrada - pytała - «żyjemy i umieramy samotni»?” (M. D., $30 \mathrm{~V}$ I946). Kowalska na różne sposoby starała się ustanowić granicę wyznań w korespondencji z Dąbrowską, co jakiś czas ustalając nowe strefy milczenia. Sugerowała zagrożenie wykluczeniem społecznym.
\Kochana, ja nie piszę o rzeczach osobistych, nie dlatego że nie znaczą one dla mnie - pękam z nadmiaru, tylko że o ile nie chcemy sławy procesu Wilde' ${ }^{3^{30}}$, bezpieczniej o tych rzeczach nie mówić, a potem - istnieje kilka zon milczenia. Wymawiasz mi tchórzostwo - ja zawsze się boję - mojej odwagi (A. K., 29 X I946).

Niebezpiecznym igraniem z granicami, wyznaczonymi intymnym wyznaniom była wzajemna lektura swoich dzienników, w których zapisywały to, czego nie miały śmiałości napisać w listach. Czytały swoje dzienniki czasami za obopólną zgodą, czasami bez niej, ale równocześnie $z$ wielką przykrością przyjmowały ich treść. To jakby świadome igranie z losem i wrażliwością drugiej osoby, wymyślna manipulacja psychiczna, będąca rodzajem wzajemnego nękania.
》Otóż teraz zdaje mi się czasami, że ja jednak jestem trochę lepsza niż to, co o mnie zawsze w dziennikach Twych wypisywałaś, a w co ja też jak w ewangelię wierzyłam i to mnie b[ardzo] przygnębiało (M. D., I5 IV I946).

Wydawać by się mogło, że Dąbrowska zaczęła z czasem akceptować granice intymnego związku wyznaczone przez Kowalską, ale była to krótkotrwała rezygnacja z marzeń, bo niebawem pisarka znów stawiała sprawę na ostrzu noża, wysuwając propozycje, które w istocie oznaczały nie tylko zawłaszczanie uczuć, ale i życia rodzinnego.

\section{\Jeśli Ty chcesz ze mną być - mój dom jest zawsze dla Ciebie otwarty-i z niego tylko mogą iść dla nas perspektywy na życie nasze własne. Jeśli chodzi o sytuacje przykre czy uwłaczające, to prze-}

30 Oscar Wilde został aresztowany 6 kwietnia 1895 r. i oskarżony o kontakty homoseksualne. Skazano go na dwa lata ciężkich robót i osadzono w więzieniu w Reading pod Londynem. Jego żona pod zmienionym nazwiskiem Constance Holland wyjechała wraz z dziećmi z kraju. 
bywanie pod jednym dachem ze sędziwym ojcowskim przyjacielem jest niebem $\mathrm{w}$ porównaniu $\mathrm{z}$ bytowaniem między łóżkiem i wózkiem dwu tak agresywnych witalnie istot jak Twój mąż i twoje dziecko. Zrzuć pychę z serca. Nie jesteś w stanie dać sobie rady ze sobą i swym życiem, i swoją naturą. Zaufaj mnie. [...] Nasze współżycie może być dla Ciebie bodźcem i pomocą do rozpoczęcia nowego życia i nowej kariery. Dla mnie - w ogóle ocaleniem od pójścia na dno. Chyba że mnie przestałaś kochać (M. D., 26-27 VIII I946).

Widoczne wyciszenie się psychiczne Dąbrowskiej nastąpiło dopiero wówczas, gdy po narodzinach Tuli możliwe stały się jej regularne wizyty we Wrocławiu, a potem przyjazdy Kowalskiej na Polną; pozwalały one powoli wracać do dawnych więzi, rozmów, bezpośredniej intymności. Zmienił się charakter listów - znikają wyraziste aluzje do fizycznych kontaktów, dramatyczne apele, pretensje i wymówki. Dąbrowska próbowała też powrócić do pracy literackiej.

Nową, nieprzewidzianą granicę rozmowy intymnej w listach wyznaczyła choroba Jerzego Kowalskiego. Pierwsza reakcja Dąbrowskiej na wieść o jego niepokojących dolegliwościach, które pojawiły się styczniu 1947 roku, była spokojna i rzeczowa. Po konsultacji z zaprzyjaźnionym lekarzem, domyślała się przyszłego przebiegu choroby. Jej listy straciły poprzednią drapieżność, wypełniała je sprawami literatury, towarzyskimi i domowymi. Czytane z perspektywy świadectwa epoki - są bogate w fakty, opisy wydarzeń i spotkań, refleksji z lektur. Także Kowalska, początkowo nieświadoma zbliżającej się tragedii, o chorobie męża pisała powściągliwie, mimochodem i jakby na marginesie innych spraw. Wobec nieznanego także i Dąbrowska postawiła sobie pewne ograniczenia w pisaniu wszystkiego, co dyktowało jej uczucie. „Czuję, że coś powinno się stać - dla nas - dla mnie, ale nie wiem już co?” (M. D., 23 I 1947) - pisała enigmatycznie. W miarę jak stawało się jasne, że choroba męża jest śmiertelna, optyka zwierzeń Anny uległa zmianie. Inny też stał się język jej listów - odtąd był surowy i powściągliwy. Napisała, stawiając innego rodzaju granicę intymności: „Nie mam natchnienia, aby Ci coś odpowiednio miłego napisać w odpowiedzi na Twoje wyznania przyjaźni. Czuję się jak popiół z piołunów" (A. K., 5 X 1947). I w następnym liście:

\Staram się, żeby utrwalić dobre poczucie J[erzego], kiedy już jest b[ardzo] chory, naprowadzam rozmowę na bombę atomową: groza powszechnej zagłady łagodzi lęk osobisty. Zresztą J[erzy] jest naprawdę stoikiem i prowadzimy przyjemne rozmowy o śmierci. [...] Twoje dobre słowa dodają mi sił, tych dobrych sił, nic z zaciętości, dumy i odrazy, które są moją rezerwą (A. K., 6 X 1947). 
W tej nowej sytuacji Dąbrowska zachowywała się niezręcznie. Nie znajdywała właściwych słów, interesowały ją sprawy nieważne, o Jerzego Kowalskiego pytała mimochodem.

\section{\Napisz - donieś, co z Twoimi biedami wszystkimi a wszystkimi. A co w naszym ogrodzie? Czy rzodkiewki wyrosły? Czy goździki i bratki rosną - czy będziesz je przesadzała? Czy macie jeszcze pieniądze? Czy kwitną chryzantemy? Czy myślisz o mnie czasem? Sądząc z Twego listu, p. Jerzy nie ma się gorzej, co już jest dobrym znakiem. Jakoś wciąż trudno mi uwierzyć w tę diagnozę. Czy czujesz, że jestem przy Tobie we wszystkim? Kochana - Całuję Cię najczulej i tulę do serca biedną skołataną głowinę, twoja M. A może zjawisz się jutro sama. Nabiłam sobie głowę tym, że przyjedziesz (M. D., II X I947).}

Czuwająca przy mężu Kowalska odpowiadała krótko, ale bez zniecierpliwienia, pisząc o trudach opieki nad umierającym, o zmęczeniu, przygnębieniu, żałości, tłumacząc się z powściągliwości relacji i odsunięcia od siebie sprawy łączącego je uczucia.

\section{》 Maryjko, piszesz, że listy moje są smutne na wszelki sposób. Wiem, że muszą być nieprzyjemne i aż rażąco pozbawione tego, co stanowi naszą - Twoją i moją wspólnotę. Moja droga, wprost uginam się pod każdym dniem. Są ciężkie, cięższe niż potrafię, niż mogę opisać. Cza- sem człowiek wstydzi się własnego cierpienia (A. K., I6-I8 X 1947).}

Los postawił temu związkowi kolejną granicę, którą Dąbrowska akceptowała z trudem, poniewczasie tłumacząc się ze swojej niedelikatności, innym razem brnąc w niestosowność. „Jak, czy, kiedy, skończą się Twoje biedy? Kiedy słoneczko trochę nam zajaśnieje?” - pytała (M. D., 22 X I947). Kowalską męczyła zdawkowość słów i ich „niewystarczalność” wobec zbliżającej się katastrofy. Intymność towarzysząca opiece nad cierpiącym, ale ciągle jeszcze wierzącym w cud wyzdrowienia mężem stała w sprzeczności z niemożnością dawania świadectwa uczucia w listach do Dąbrowskiej. Pozostała już tylko potrzeba odczuwania emocjonalnej bliskości przyjaciółki, chęć trzymania jej za rękę w geście szukającym pocieszenia. Miała silne poczucie niewłaściwości wszelkich deklaracji uczuciowych wobec Marii.

\Kochana, wielu rzeczy, które by były miłe Twemu sercu - teraz nie wypada mi mówić. Jestem bardzo skrępowana wewnętrznie i teraz nie pozwalam sobie na wiele zwierzeń i nadziei (A. K., 22-24 X 1947). 
Owo „wewnętrzne skrępowanie” było kolejną zaporą postawioną intymności związku z przyjaciółką. Tej wyraźnej prośby o powściągliwość Dąbrowska nie odczytała, w kolejnych listach uparcie wracając do podejrzeń dotyczących przyszłych losów ich miłości i do wcześniejszych wyrzutów i oskarżeń, dopatrując się „złych intencji i zamiarów” Kowalskiej (M. D., 29 X 1947 ). Tym samym po raz kolejny przekraczała granicę, błagalnie wyznaczoną przez udręczoną sytuacją domową przyjaciółkę.

O ile ciąża i macierzyństwo Anny były najcięższą próbą dla Marii, z której wyszła pokiereszowana psychicznie i niedobrze odmieniona, to taką próbą dla Anny była choroba męża, którego mimo wszystko kochała i wobec którego miała poczucie wdzięczności za ciekawe wspólne życie. To uwikłanie w podwójną miłość spowodowało u Anny chęć ucieczki od przytłaczającej rzeczywistości, potrzebę wyzwolenia się od wszystkiego, co ją otaczało: „Gdyby można dowolnie jeździć, wybrałabym się do Grecji i zamieszkała w jakichś ruinach, nad morzem, na zupełnie sa motnym brzegu [wyróżn. E. G.]” (A. K.,

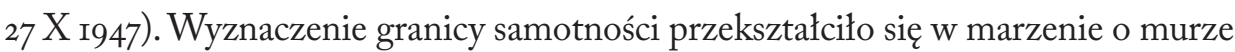
odgradzającym od nieprzyjaznego świata, także od związku, który zaczął ciążyć nad jej życiem. Od przyjaciółki oczekiwała uszanowania ograniczeń, wynikających z sytuacji, postawieniu tamy nagłym, nieprzejednanym pretensjom: „zdumiewa mnie bez granic Twoja zdolność nierozumienia, niewidzenia”(A. K., I XI 1947).

Styczeń 1948 roku to był czas oczekiwania na śmierć Kowalskiego. Anna pierwsza przekroczyła granicę „niewysłowionego”, pisząc pod koniec choroby męża:

\Załatwiaj swoje sprawy i bądź o mnie spokojna. Ale gdy załatwisz, to byłoby pożądane $\mathrm{z}$ wszystkich względów, abyś przyjechała na długo. Jest to ważne nie tylko ze względu na mieszkanie, ale na mnie - w całej żałości i żałobie szczerej i prawdziwej - jest uparta nadzieja życia z Tobą. To musi się ziścić. To jest czas, kiedy musisz walczyć, abyśmy były szczęśliwe, aby się coś nie obróciło na opak. Rozumiesz to - jestem przerażona, gdy to piszę, bo ta chwila psychicznego oczekiwania jest decydująca dla reszty naszego życia, jak Ci na tym tak zależy, jak mnie (A. K., i9 I 1948).

Dąbrowska, jak stwierdziła - „niezdolna pisać niewyrażalnego” - nazwała te dni „ambiwalencją uczuć”: „Smutek jest przeniknięty jakimiś nadziejami, którym wstyd moralny nie pozwala wybuchnąć” (M. D., 20 I I948) - pisała. Następnego dnia jednak komunikowała otwartym tekstem:

\Musimy zachować spokój dla wielkiego interesu naszego szczęścia i życia. [...] Postaram się przyjechać jak najprędzej. Zrobię wszystko, 
co będzie potrzeba, żeby zachować dla nas i dla dziecka Twój dom. [...] Zostaw umarłych umarłym - żyj - ukochana (M. D., 2I I 1948).

Jerzy Kowalski zmarł następnego dnia. W przeddzień jego śmierci Kowalska napisała: „Już powiedziałam Kulczyńskiemu, że ty zajmiesz górę na Lindego, żeby mi nie raili lokatorów" (A. K., 2I I I948).

\section{RoLA EDYTORA}

Korespondencja Marii Dąbrowskiej i Anny Kowalskiej jest zespołem niezwykle interesującym, zarówno ze względu na jej szczególny, intymny charakter, jak i na rozległość wątków znajdujących w listach swoje odzwierciedlenie. Szczegóły życia osobistego przeplatają się tu z sądami o wydarzeniach politycznych i społecznych, relacje z lektur i wydarzeń kulturalnych - z opiniami o kolegach po piórze i prominentnych postaciach powojennej Polski. Listy pisarek, czytane równolegle z ich dziennikami, pokazują nadto niejednoznaczność i skomplikowanie relacji między przyjaciółkami, uwikłanymi w związek, który przyniósł im tyleż szczęścia, co goryczy.

Publikacją listów musi rządzić zasada poszanowania intymności, którą edytor powinien uwzględnić. Dotyczy to, rzecz zrozumiała, przede wszystkim listów miłosnych. Wydając listy, w każdym przypadku, gdy naruszenie tej zasady może skutkować uszczerbkiem wizerunku autora, nieustannie podejmujemy decyzje dotyczące upublicznienia faktów, opinii, relacji i skrywanych uczuć. Edycja listów intymnych osób związanych uczuciem homoseksualnym wydaje się - zważywszy na niski poziom społecznej akceptacji takich związków - szczególnie trudnym wyzwaniem. Ważna jest przede wszystkim kwestia, czy korespondenci/korespondentki biorą pod uwagę przyszłą ich publikację. Jeżeli chodzi o Marię Dąbrowską, można założyć, że wzorem praktyki dotyczącej korespondencji z mężem i Stanisławem Stempowskim, myślała o przysposobieniu listów do druku, na co wskazuje sporządzenie przez nią przeredagowanych odpisów. Zwierzała się w tej sprawie Kowalskiej:

\section{》 Myślę coraz częściej, że powinnyśmy opracować obiektywną stronę naszych listów, gdyż ich treść na pewno przyda się kiedyś światu. Oto się nazywa „dyskontowanie uczuć”. Lecz ważne jest, w imię czego się „dyskontuje” (M. D., 24 VII I948).}

Autorka Nocy i dni zgodę na publikację swojej korespondencji wyraziła zapisem testamentowym, wyznaczając jedynie cezurę czasową (5o lat po śmierci) i nie stawiając 
innych ograniczeń, dotyczących choćby cenzurowania treści. Zgodnie z paragrafami prawa autorskiego Anna Kowalska takiej akceptacji dawać nie musiała, ponieważ jej listy, gdy tylko dotarły do adresatki, stały się własnością Dąbrowskiej. Istotne znaczenie ma też fakt, że zgodę na publikację listów wyrazili Spadkobiercy obu pisarek.

Przygotowanie tej edycji jest zadaniem karkołomnym. Największą komplikacją jest wielkość tego zbioru: 2343 obustronnie pisanych obszernych listów to około 7000 stron maszynopisu. W sytuacji gdy rozmiar korespondencji uniemożliwia wydanie jej w całości, a jedynie w reprezentatywnym, możliwie obszernym wyborze, odpowiedzialność za kształt udostępnionej szerokiemu gronu czytelników korespondencji spada na edytora. A biorąc pod uwagę fakt, że nie wszystkie napisane listy autorki wysyłały adresatce, edytor musi przyjąć odpowiedzialność za właściwy ich dobór i w tym zakresie. „Jakżeż listy mylą! A może nie listy. Może rzeczywistość myli” - napisała Anna Kowalska w liście do Marii Dąbrowskiej z 22 maja I947 roku, jakby przeczuwając piekło przyszłego edytora ${ }^{3 \mathrm{I}}$.

\section{Bibliografia:}

Borkowska G., Maria Dąbrowska i Stanistaw Stempowski, Kraków 1999;

Cabaj R., W cieniu Anny Kowalskiej, „Pomosty” t. 9: 2004, s. 241-244;

Dąbrowska M., Dzienniki 1914-1965. Pierwsze pełne wydanie w 13 tomach (bez opracowania edytorskiego) pod kierunkiem T. Drewnowskiego, Warszawa 2009;

Głębicka E., Dąbrowska (nie)znana, Warszawa 2016;

Dylematy edycji korespondencji intymnej Marii Dabrowskiej i Anny Kowalskiej, „Teologia Polityczna co Tydzień" 2018, nr 97 [http://teologiapolityczna.pl];

Kochańczyk A., Rozmowy o mitości, „Akcent” 2006, nr 4, s. 28-35;

Kowalska A., Dzienniki 1927-1969, Warszawa 2008;

Kraskowska E., Maria Dąbrowska i Anna Kowalska, w: Polskie pisarstwo kobiet w wieku XX. Procesy i gatunki, sytuacje i tematy, red. B. Kaniewska, E. Kraskowska, Poznań 2015;

Pierzchała J., Świat Anny Kowalskiej, „Śląsk” 2002, nr 11, s. 44-46;

Thum G., Obce miasto. Wroctaw 1945 i potem, tłum. M. Słabicka, Wrocław 2008;

Tomasik K., Czy wielki pisarz może być lesbijką? O Marii Dąbrowskiej, w: idem, Homobiografie, Warszawa 2008;

Świerkosz M., Arachne i Atena. W strone innej poetyki pisarstwa kobiecego, „Teksty Drugie” 2015, nr 6, s. 70-90.

SŁowa KLucze: Maria Dąbrowska - korespondencja; Anna Kowalska - korespondencja; epistolografia - XX wiek

31 Planowana edycja w sześciu tomach obejmie ponad połowę listów znajdujących się w tym zespole. O decyzji wydania korespondencji w wyborze pisałam w: Dylematy edycji korespondencji intymnej Marii Dąbrowskiej i Anny Kowalskiej, „Teologia Polityczna co Tydzień” 2018, nr 97 [http://teologiapolityczna.pl; stan z 5 lutego 2018 r.]. 


\section{Ewa GŁĘBicka}

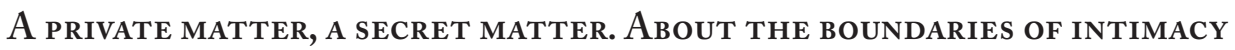
in the correspondence between Maria Dąbrowska and Anna KowalSKA IN I946-I948

The article about unstable boundaries of intimacy in the correspondence between Maria Dąbrowska and Anna Kowalska was based on 600 of both wrriters letters from 1946 to 1948. It was the most difficult time of their secret relationship with its most dramatic moments: being Anna's pregnancy which was hard to accept by Dąbrowska, the birth of the child, and the period soon after the death of Jerzy Kowalski. These events were accompanied by intensive and impetuous correspondence, which proves how difficult this love was, marked, on the one hand, by a conviction to its right of existence, and on the other, by misunderstanding, humiliation, and the struggle for one's own freedom to make life choices independent of friend's will. The letters became the only way of communication between both womem for a longer period of time, which was necessary but unreliable and insufficient to name what's "inexpressible". Written words replaced closed contact but also hurt and deceived, without expressing the truth about this difficult relationship. The tone of their correspondence sometimes resembles a battlefield, and later careful peace negotiations and compromises, which were exceptionally difficult when one party demanded exclusivity, whereas the other - set boundaries and expected them to be respected. The letters read along with the writers' journals present ambiguity and complexity of the relationship between two friends, entangled in a relationship which brought them both happiness and bitterness as well.

The author highlights also the difficulties connected with the planned publication of this correspondence. The entire set of letters of the years from 1940 to 1965 counts I353 multi-page letters written by Dąbrowska and 990 letters written by Kowalska (often not dated). Taking into account the size of this set of letters (what makes it impossible to publish as a whole) and also the character of the correspondence, the author suggests to publish a representative set of letters, most extensively selected.

KeY words: Maria Dąbrowska - correspondence; Anna Kowalska - correspondence; epistolography $-20^{\text {th }}$ century 